\title{
Ascospore Release and Infection of Apple Leaves by Conidia and Ascospores of Venturia inaequalis at Low Temperatures
}

\author{
Arne Stensvand, David M. Gadoury, Terje Amundsen, Lars Semb, and Robert C. Seem
}

First, third, and fourth authors: Norwegian Crop Research Institute, Plant Protection Centre, Department of Plant Pathology, N-1432 Ås, Norway; second and fifth authors: Department of Plant Pathology, Cornell University, New York State Agricultural Experiment Station, Geneva, NY 14456.

Accepted for publication 2 July 1997.

\begin{abstract}
Stensvand, A., Gadoury, D. M., Amundsen, T., Semb, L., and Seem, R. C. 1997. Ascospore release and infection of apple leaves by conidia and ascospores of Venturia inaequalis at low temperatures. Phytopathology 87:1046-1053.

Mills' infection period table describes the number of hours of continuous leaf wetness required at temperatures from 6 to $25^{\circ} \mathrm{C}$ for infection of apple leaves by ascospores of Venturia inaequalis and reports that conidia require approximately two-thirds the duration of leaf wetness required by ascospores at any given temperature. Mills' table also provides a general guideline that more than 2 days of wetting is required for leaf infection by ascospores below $6^{\circ} \mathrm{C}$. Although the table is widely used, infection times shorter than those in the table have been reported in lab and field studies. In 1989 a published revision of the table eliminated a potential source of error, the delay of ascospore release until dawn when rain begins at night, and shortened the times reported by Mills for ascospore infection by $3 \mathrm{~h}$ at all temperatures. Data to support the infection times below $6^{\circ} \mathrm{C}$ were lacking, however. Our objective was to quantify the effects of low temperatures on ascospore discharge, ascospore infection, and infection by conidia. In two of three experiments at $1{ }^{\circ} \mathrm{C}$, the initial release of ascospores occurred after 131 and $153 \mathrm{~min}$. In

the third experiment at $1{ }^{\circ} \mathrm{C}$, no ascospores were detected during the first $6 \mathrm{~h}$. The mean time required to exceed a cumulative catch of $1 \%$ was 143 min at $2^{\circ} \mathrm{C}, 67 \mathrm{~min}$ at $4^{\circ} \mathrm{C}, 56 \mathrm{~min}$ at $6^{\circ} \mathrm{C}$, and $40 \mathrm{~min}$ at $8^{\circ} \mathrm{C}$. At 4,6 , and $8^{\circ} \mathrm{C}$, the mean times required to exceed a cumulative catch of $5 \%$ were 103,84 , and $53 \mathrm{~min}$, respectively. Infection of potted apple trees by ascospores at $2,4,6$, and $8^{\circ} \mathrm{C}$ required $35,28,18$, and $13 \mathrm{~h}$, respectively; substantially shorter times than previously were reported. In parallel inoculations of potted apple trees, conidia required approximately the same periods of leaf wetness as ascospores at temperatures from 2 to $8^{\circ} \mathrm{C}$, rather than the shorter times reported by Mills or the longer times reported in the revision of the Mills table. We propose the following revisions to infection period tables: (i) shorter minimum infection times for ascospores and conidia at or below $8^{\circ} \mathrm{C}$, and (ii) because both ascospores and conidia are often present simultaneously during the season of ascospore production and the required minimum infection times appear to be similar for both spore types, the adoption of a uniform set of criteria for ascosporic and conidial infection based on times required for infection by ascospores to be applied during the period prior to the exhaustion of the ascospore supply. Further revisions of infection times for ascospores may be warranted in view of the delay of ascospore discharge and the reduction of airborne ascospore doses at temperatures at or below $2^{\circ} \mathrm{C}$.
\end{abstract}

The apple scab pathogen, Venturia inaequalis (Cooke) G. Wint. (anamorph Spilocaea pomi Fries), overwinters primarily as pseudothecia in apple leaf litter. During spring rains, ascospores are released from pseudothecia and cause infections of leaves, blossoms, young shoots, and fruits of apple. In the absence of significant sources of conidial primary inoculum $(2,18,19,24,36)$, control of apple scab is achieved by intensive applications of fungicides intended to prevent infections by ascospores (20).

Fungicide applications for control of apple scab can be applied in response to discrete infection periods. Mills (26) described the minimum number of hours of continuous wetness required for leaf infection by ascospores at temperatures from 6 to $25^{\circ} \mathrm{C}$. For all temperatures below $6^{\circ} \mathrm{C}$, Mills (26) reported that more than 2 days of wetting was required for infection by ascospores. Mills and Laplante (27) reported that infection by conidia required only twothirds the duration of wetting required by ascospores at a given temperature. At least two major revisions have been made to Mills' original table (26). Jones and Aldwinkle (14) reduced the times required for infection at temperatures below $9^{\circ} \mathrm{C}$ but did not cite the basis for this revision. MacHardy and Gadoury (22) sug-

Corresponding author: D. M. Gadoury; E-mail address: dmg4@ cornell.edu

Publication no. P-1997-0821-01R

(C) 1997 The American Phytopathological Society gested several changes to the Mills table. First, because significant ascospore discharge is delayed until dawn when rain begins at night, MacHardy and Gadoury (22) recommended that infection times be computed from $0700 \mathrm{~h}$. after night rains. Second, MacHardy and Gadoury (22) speculated that delayed ascospore release during darkness had inflated the times reported for ascospore infection by Mills and recommended that the times reported by Mills be reduced by $3 \mathrm{~h}$ at all temperatures. Last, because several authors $(16,17,28-32,37)$ had reported minimum infection times for conidia that were equal to or longer than those for ascospores at equivalent temperatures, MacHardy and Gadoury (22) generated a new equation, based on the published data, to describe the minimum infection times for conidia.

Despite these changes to Mills' original table, the validity of the table at temperatures below $6^{\circ} \mathrm{C}$ is unknown. Mills' (27) recommendation that more than 2 days of wetting is required below $6^{\circ} \mathrm{C}$ was considerably less precise than the discrete times provided for 6 to $25^{\circ} \mathrm{C}$. Reports by other authors $(15-17,28-32,37)$ contain little, if any, data on infection below $5^{\circ} \mathrm{C}$.

Rain events at temperatures below $6^{\circ} \mathrm{C}$ are common in the northeastern parts of the United States and Canada and in northern Europe for up to 6 weeks after bud break of apple, which is also the major period of ascospore release for $V$. inaequalis. Our first objective was to more precisely define the minimum number of hours required for infection of apple foliage by ascospores and conidia of $V$. inaequalis at low temperatures. 
The impact of low temperature on ascospore release has not been considered in development of currently used infection period tables. Although not part of the infection process per se, delayed discharge of inoculum at low temperatures would delay infection. The rate of ascospore release by $V$. inaequalis is reduced at temperatures below $10^{\circ} \mathrm{C}(10,13,21)$, and the reduction is greatest when temperatures approach $0^{\circ} \mathrm{C}(10,13)$. Above $10^{\circ} \mathrm{C}$, there may be little or no effect of temperature on the rate of release (33). Both Hirst and Stedman (13) and MacHardy and Gadoury (21) observed that cumulative distributions of ascospore release were shifted in time by $\sim 2$ to $3 \mathrm{~h}$ when temperatures during natural rain events were below 10 to $12^{\circ} \mathrm{C}$ compared to distributions above 10 to $12^{\circ} \mathrm{C}$. However, the quantitative impact of temperatures between 0 and $10^{\circ} \mathrm{C}$ on the rate of spore release is poorly understood. Our second objective was to quantify the effects of temperature on release of ascospores of $V$. inaequalis.

\section{MATERIALS AND METHODS}

Plants. Apple cvs. Vista Bella and Lobo grafted on MM106 or M26 rootstocks were grown in 0.5-liter pots to a height of 20 to $40 \mathrm{~cm}$. Both cultivars are highly susceptible to apple scab. The plants were grown at 15 to $25^{\circ} \mathrm{C}$ in a shaded greenhouse. Additional light from high-pressure sodium lamps was supplied during the spring and fall, and the plants were fertilized frequently to ensure vigorous growth of young, susceptible foliage.

Inoculum. Ascosporic inoculum was obtained from leaves collected in a university research orchard in Ås, Norway. Fallen, infected leaves were overwintered on the ground in the orchard. When the first ascospores matured during April, the leaves were collected and stored at $-18^{\circ} \mathrm{C}$. Two to three weeks before each inoculation, leaves were moistened and incubated for fourteen days at $12^{\circ} \mathrm{C}$ in darkness. Before inoculation, the leaves were airdried at 20 to $25^{\circ} \mathrm{C}$ for 2 to $4 \mathrm{~h}$.

Conidia were washed with distilled water from Vista Bella and Lobo leaves bearing young apple scab lesions. The leaves either were freshly collected or were collected the previous year and stored at $-18^{\circ} \mathrm{C}$ until use. Conidial suspensions were maintained at $5^{\circ} \mathrm{C}$ and adjusted to $10^{5}$ spores per $\mathrm{ml}$ prior to application to plants.

Inoculation of potted trees. Leaves containing pseudothecia were placed on top of a wire screen with a mesh size of $2.5 \times 3 \mathrm{~cm}$. The leaves were wetted outside the controlled-environment chambers at room temperature by spraying both upper and lower surfaces thoroughly with tap water at a temperature of 10 to $15^{\circ} \mathrm{C}$. To ensure that initial inoculation with ascospores coincided with the starting time of each wetting period, leaves were allowed to remain at room temperature for $5 \mathrm{~min}$ after wetting to stimulate ascospore release. Five minutes after wetting, the screen bearing the leaves was placed within a controlled-environment chamber operating at the desired temperature and containing the potted trees to be inoculated. The screen was supported by a steel frame, which was draped in a clear polyethylene sheet to maintain surface water on both the overwintered leaves and the potted trees, 10 to $15 \mathrm{~cm}$ above the plants. The overwintered leaves were kept over the plants during the entire wetting period. Four microscope slides were placed in each enclosure with the plants and were mounted adjacent to the upper leaves. The slides were removed from the chambers 12 to $15 \mathrm{~h}$ after inoculation, air-dried, and prepared for examination. The microscope slides represented the quantity of ascospores deposited on the leaves. Two to four transections along the long axis of each slide were examined at $200 \times$. The average number of spores per square centimeter of glass slide area was recorded.

To supply light sufficient for maximum ascospore release $(4,10)$, a $50-\mathrm{W}$ incandescent light bulb was suspended within the chamber. To prevent uneven temperatures between and within the plants because of heating from the light, the light source was kept 50 to
$60 \mathrm{~cm}$ from the plants. Two temperature sensors were used in each chamber when the light was on. One was placed among the uppermost leaves, which were exposed to the light, and the other was kept in the shade of the lowermost leaves.

Potted trees also were sprayed to runoff with conidial suspensions $\left(10^{5}\right.$ spores per $\left.\mathrm{ml}\right)$. Droplets of the spore suspension were placed on glass microscope slides, which were incubated in a petri plate for $24 \mathrm{~h}$ at room temperature. The percentage of germinated conidia was determined at $200 \times$. Potted trees inoculated with conidia were not exposed to supplemental light.

Controlled-environment chambers. The experiments were carried out in four temperature-regulated chambers, each maintained at a temperature between 2 and $8^{\circ} \mathrm{C} \pm 0.2^{\circ} \mathrm{C}$. Five Vista Bella or Lobo potted trees were placed in each of the four chambers for each run of the experiment. Chamber temperatures were monitored at 0.5 -min intervals by electronic data loggers, either a TL10 (EV Systems, Fino Mornasco, Italy) with an accuracy of $\pm 0.2^{\circ} \mathrm{C}$ or an MI-1444 1590TC (United Systems Corporation, Dayton, $\mathrm{OH})$ with an accuracy of $\pm 0.1^{\circ} \mathrm{C}$, equipped with thermocouple temperature sensors prepared from copper and constantan wire. The potted trees were placed in the chambers 2 to $3 \mathrm{~h}$ before inoculation to cool the plant tissue to the same temperature as the ambient air. To maintain leaf wetness, the chambers were opened momentarily while the leaves were sprayed with cold $\left(2\right.$ to $\left.8^{\circ} \mathrm{C}\right)$ water every 2 to $4 \mathrm{~h}$.

Incubation of plants and assessment of disease. At 10 to $28 \mathrm{~h}$ after inoculation and at 2-h intervals thereafter, a single potted tree was removed from each chamber. Leaves on plants were dried gently with paper towels and air from a hand-held fan and moved to a climate chamber in a greenhouse for incubation. During incubation, the temperature of the climate chamber was kept at 15 to $25^{\circ} \mathrm{C}$, and the relative humidity was kept at 50 to $90 \%$. Three to four weeks after inoculation, the number of sporulating scab lesions on each leaf and shoot was recorded.

Experimental design and data analysis. The minimum infection time was defined as the minimum wetness period required to produce any lesions on any shoot of a potted tree. The experimental unit was a single potted tree removed from the controlledenvironment chamber at a certain time after inoculation. Four temperature treatments were used simultaneously: one in each of the four controlled-environment chambers in each run of the experiment. Results of three runs of the experiment were treated as replicates. The experiment was conducted with cv. Vista Bella and was repeated with an equal number of replications of cv. Lobo. The relationship between temperature and minimum infection time was analyzed by linear and nonlinear regression.

Ascospore release in a wind tunnel at low temperatures. Heavily infected apple leaves were collected from the Station Creek Research Orchard at Geneva, NY, when apple fruit buds were at the green-tip stage of development. The leaves were air-dried at room temperature for $24 \mathrm{~h}$ and frozen in plastic bags at $-18^{\circ} \mathrm{C}$. The leaves were removed from the freezer 12 to $18 \mathrm{~h}$ before each experiment, and 1.4-cm-diameter disks were cut from the leaves and returned to the freezer.

Ascospore release was monitored under controlled conditions in a wind tunnel described by Gadoury et al. (11). The apparatus was essentially a cylindrical tunnel under positive pressure. Compressed air was forced through a column of water to adjust relative humidity to 90 to $95 \%$. The air then entered one end of a $10-\mathrm{cm}-$ diameter tube at a rate of 20 liters/min, passed over a platform bearing the fungal sample, and exited the trap through a $2 \times 10$ $\mathrm{mm}$ orifice $20 \mathrm{~cm}$ downwind of the sample. Spores exiting the apparatus impacted on a clear plastic tape borne on a clock cylinder that revolved once every $12 \mathrm{~h}$. The temperature of the sample was monitored by a thermistor embedded in the sample platform and recorded by a data logger. Light was directed toward the sample through a fiber-optic bundle coupled to a $150-\mathrm{W}$ quartz-halogen lamp. The quality and intensity of the light was adjusted by a se- 
lective filter at the source to approximate natural daylight at $0700 \mathrm{~h}$ during May in the northeastern United States. At the $725 \mathrm{~nm}$ wavelength shown by Brook (4) to stimulate ascospore release, intensity at the sample plane was $5.2 \mu \mathrm{W} / \mathrm{cm}^{2}$. Leaf samples were illuminated throughout the experiments. Simulated rain was applied to the sample at a rate of $5.3 \mathrm{~cm} / \mathrm{h}$ through a fine-spray nozzle located $50 \mathrm{~cm}$ above the sample. The temperature of the simulated rain and air entering the tunnel, as well as a water jacket surrounding the apparatus, was controlled by passing each through a controlled temperature bath.

Before each experiment, the wind tunnel was cooled for 1 to $1.5 \mathrm{~h}$ by letting the simulated rain run and by circulating chilled water through the cooling jacket. The temperature at the sample platform was held 1 to $2^{\circ} \mathrm{C}$ below the desired temperature before the start of the experiment and was increased to the desired temperature at the start of each experiment.

Ascospore release was monitored in experiments at 1, 2, 4, 6, and $8^{\circ} \mathrm{C}$. To determine the total potential release from a leaf sample, experiments consisted of a low-temperature phase, lasting $6 \mathrm{~h}$ at $1^{\circ} \mathrm{C}$ or $3 \mathrm{~h}$ at 2 to $8^{\circ} \mathrm{C}$, followed by $3 \mathrm{~h}$ at $20^{\circ} \mathrm{C}$ to harvest the ascospores remaining in the sample after the low-temperature phase.

Additional populations of $V$. inaequalis borne on infected leaves collected from beneath unsprayed trees in Geneva, NY; Alnarp, Sweden; and Friedrichschafen, Germany, just prior to bud break were exposed to simulated rain, as described above, for $12 \mathrm{~h}$ at 1 and $2^{\circ} \mathrm{C}$, followed by $3 \mathrm{~h}$ at $20^{\circ} \mathrm{C}$. Leaf samples from Germany and Sweden were air-dried, shipped via air to Geneva, NY, and frozen at $-15^{\circ} \mathrm{C}$ until needed.

The tape bearing the ascospores was dissected, mounted in cotton blue/lactoglycerol on microscope slides, and examined at 200 to $400 \times$. The number of ascospores was recorded in transects across the long axis of the tape at 4-mm intervals, which corresponded to time intervals of $5 \mathrm{~min}$.

Ascospore release model development. The cumulative data collected on ascospore release between 0 and $6 \mathrm{~h}$ after initial wetting at 1 to $8^{\circ} \mathrm{C}$ were modeled on time and temperature by logistic regression techniques for all data (25). At the lowest temperatures, because 5-min intervals often elapsed without detectable ascospore release, discharge counts were grouped by 10-min intervals for the purposes of fitting. The cumulative discharge function was

$$
F_{t q}=1-\left[\frac{1}{1+\exp \left(\eta_{t q}\right)}\right]
$$

where $F=$ cumulative discharge, $t=\log _{e}$ time, $q=\log _{e}$ temperature (degrees Celsius), and $\eta_{t q}=b_{0}+b_{1} t+b_{2} t^{2}+b_{3} t^{3}+b_{4} q+$ $b_{5} t q+b_{6} t^{2} q+b_{7} t^{3} q$, which is a polynomial in log-time and log-

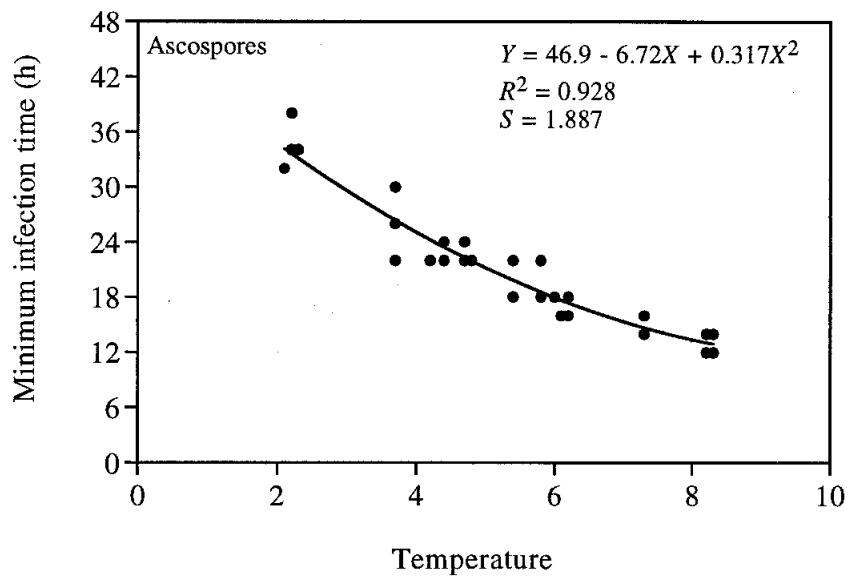

Fig. 1. Minimum number of hours of leaf wetness required for ascospores of Venturia inaequalis to infect potted trees of apple cvs. Vista Bella and Lobo at various temperatures from 2 to $8^{\circ} \mathrm{C}$. temperature. Estimates of the coefficients and their respective standard errors were

$$
\begin{aligned}
& b_{0}=131.0 \pm 21.38 \\
& b_{1}=-117.2 \pm 15.04 \\
& b_{2}=29.92 \pm 3.546 \\
& b_{3}=-2.397 \pm 0.2778 \\
& b_{4}=-147.1 \pm 14.23 \\
& b_{5}=107.6 \pm 9.786 \\
& b_{6}=-25.07 \pm 2.251 \\
& b_{7}=1.916 \pm 0.1723
\end{aligned}
$$

Simple linear regression also was used to describe the release of ascospores at 1 and $2^{\circ} \mathrm{C}$ and yielded the following:

$$
Y=-0.304+0.00262 X
$$

$R^{2}=0.997$, where $Y=$ cumulative discharge (percent) at $1^{\circ} \mathrm{C}$, and $X=$ time (minutes) after initial wetting and

$$
Y=-1.258+0.0169 X
$$

$R^{2}=0.817$, where $Y=$ cumulative discharge (percent) at $2{ }^{\circ} \mathrm{C}$, and $X=$ time (minutes) after initial wetting.

\section{RESULTS}

Infection experiments. The mean density of the ascospore deposit on glass slides in the inoculation chamber was 442, 700, 1,426 , and $708 / \mathrm{cm}^{2}$ at $2,4,6$, and $8^{\circ} \mathrm{C}$, respectively, with a mean germination rate of $>80 \%$ for all temperatures. Germination of conidia exceeded $70 \%$ in each experiment. Proximity of leaves to the supplemental light used to stimulate ascospore release did not substantially affect temperature. The difference in temperature recorded by an exposed sensor near the uppermost leaves and a sensor shaded by the lowermost leaves was $0.2^{\circ} \mathrm{C}$ or less at all temperatures.

Within each inoculum type (ascosporic or conidial), there were no significant differences between minimum times for infection of Vista Bella and Lobo trees at any temperature at $P=0.10$. Therefore, data from Vista Bella and Lobo trees were pooled after homogeneity of variance was confirmed, and regression analysis was used to describe the relationship between temperature and minimum time required for infection by ascospores (Fig. 1) and conidia (Fig. 2). In both cases, the best fit was provided by a seconddegree polynomial. The respective equations were, for ascospores:

$$
Y=46.9-6.72 X+0.317 X^{2}
$$

$R^{2}=0.928$ and $S=1.887$, and for conidia:

$$
Y=41.5-4.17 X+0.111 X^{2}
$$

$R^{2}=0.898$ and $S=2.579$, where $Y=$ the minimum number of

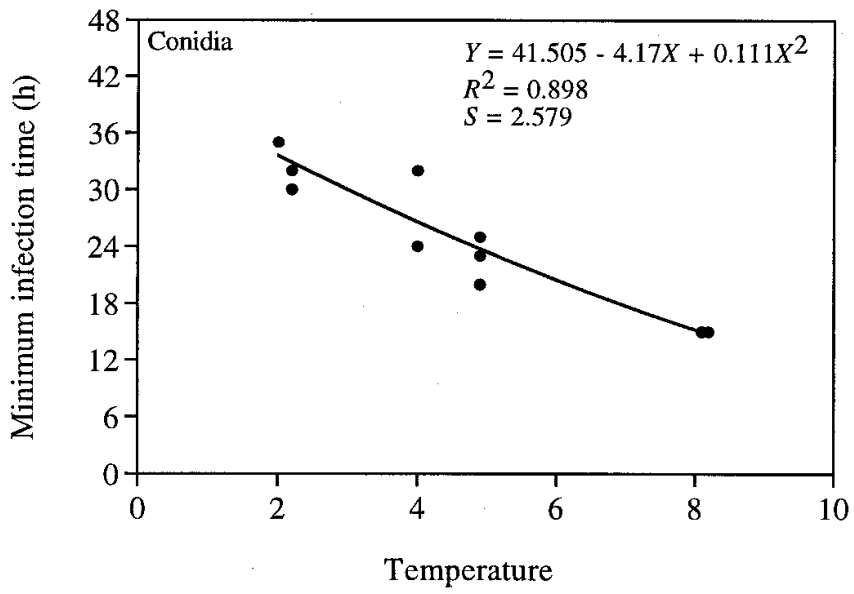

Fig. 2. Minimum number of hours of leaf wetness required for conidia of Venturia inaequalis to infect potted trees of apple cvs. Vista Bella and Lobo at various temperatures from 2 to $8^{\circ} \mathrm{C}$. 
hours of continuous wetness required for infection, and $X=$ the temperature during wetting.

Expected values for ascospores generated by equation 4 differed by less than $2 \mathrm{~h}$ from those for conidia generated by equation 5 . For example, at $2,4,6$, and $8^{\circ} \mathrm{C}$ the differences between expected times required for infection by ascospores and conidia were 1.1, $1.2,1.5$, and $1.8 \mathrm{~h}$, respectively.

Ascospore release at low temperatures. Low temperature had three pronounced effects on ascospore release. First, low temperatures resulted in a lag phase in the cumulative distribution of ascospore release, during which few or no ascospores were detected (Fig. 3). The time until first detection of a given quantity of inoculum was inversely proportional to temperature. In two of three experiments at $1^{\circ} \mathrm{C}$, the initial release of ascospores occurred after 131 and $153 \mathrm{~min}$. In the third experiment at $1^{\circ} \mathrm{C}$, no ascospores were detected until the temperature was raised during the final $3 \mathrm{~h}$ of the experiment. The mean time required to exceed a cumulative catch of $1 \%$ was $143 \mathrm{~min}$ at $2^{\circ} \mathrm{C}, 67 \mathrm{~min}$ at $4^{\circ} \mathrm{C}, 56 \mathrm{~min}$ at $6^{\circ} \mathrm{C}$, and $40 \mathrm{~min}$ at $8^{\circ} \mathrm{C}$ (Fig. 3). At 4,6 , and $8^{\circ} \mathrm{C}$, the mean times required to exceed a cumulative catch of $5 \%$ were 103,84 , and $53 \mathrm{~min}$, respectively (Fig. 3).

The second major effect of low temperatures was a reduction of the rate of release, recognizable as an increase in the slope of cumulative distributions of ascospore release as temperature increased from 1 to $8^{\circ} \mathrm{C}$ (Fig. 3). Consequently, as the third major effect of low temperature, there was a reduction of the absolute number of ascospores released at any given time.

Ascospore release was described accurately by the logistic regression model at all temperatures for up to $6 \mathrm{~h}$ after initial wetting. Coefficients of correlation ranged from 0.87 at $1.0^{\circ} \mathrm{C}$ to 0.99 at $8.0^{\circ} \mathrm{C}$ (Fig. 4 and Table 1). Release of ascospores at 1 and $2^{\circ} \mathrm{C}$ between 6 and $12 \mathrm{~h}$ after initial wetting was most accurately described by simple linear regression (Table 1 ).

\section{DISCUSSION}

Ascospore release and infection at low temperatures. Our studies of the effects of temperature on ascospore release confirm and extend the major findings of earlier works $(13,21,33)$. Temperatures of $2{ }^{\circ} \mathrm{C}$ or less nearly stop the process of ascospore discharge. Because ascospore release also is suppressed in darkness $(3,4,7,13,21)$, there is a potential for additive effects of low temperatures and light. For example, if a cold rain event began during late afternoon, when darkness was only a few hours away, significant ascospore release might be delayed until dawn, whereas at warmer temperatures release could begin immediately after wetting. Additionally, in situations in which airborne ascospore dose would ordinarily be near a threshold level for significant infection under the most favorable temperatures, the reduction of airborne ascospore dose at temperatures near freezing may result in an ab-

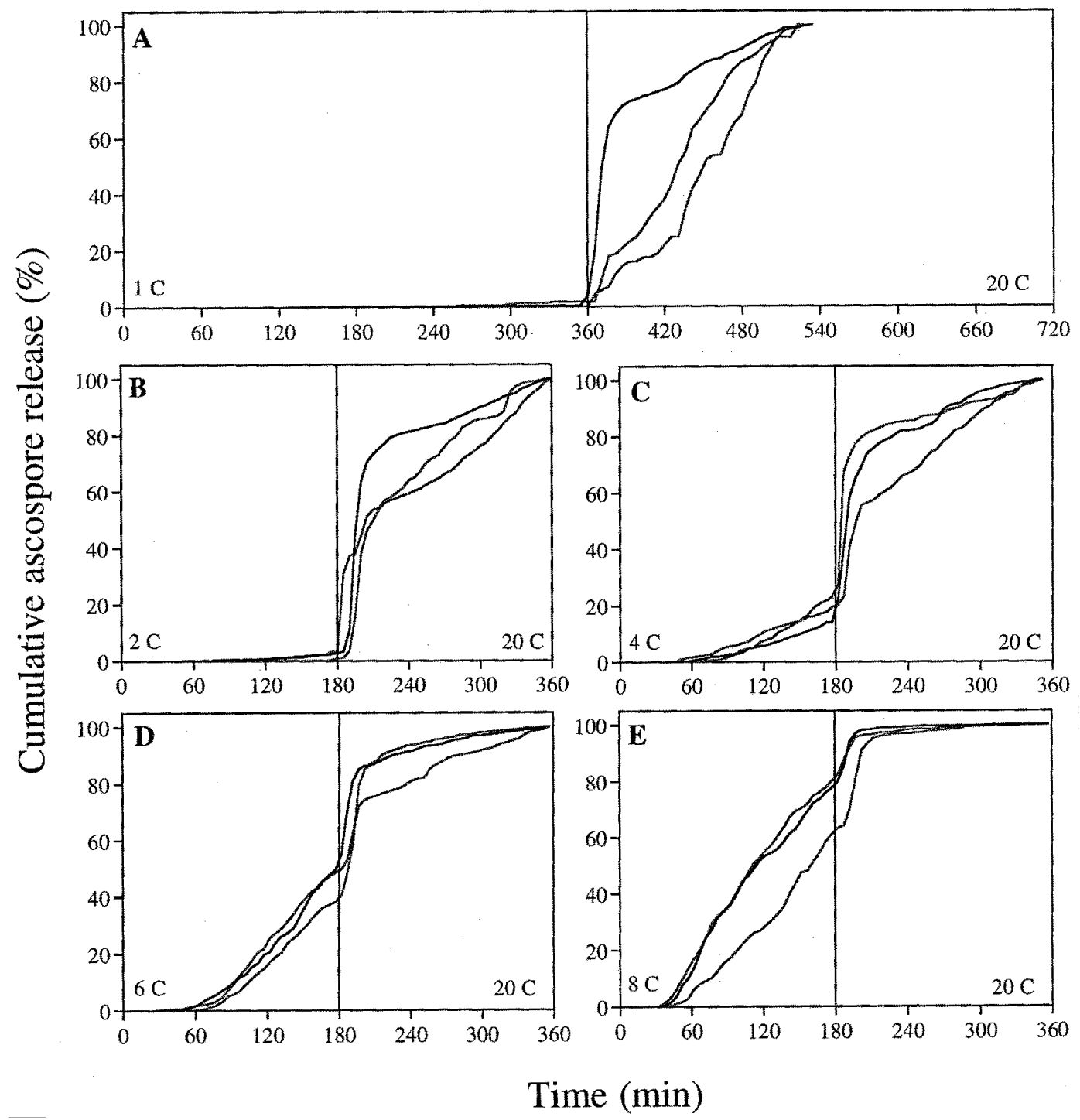

Fig. 3. The relationship between temperature and cumulative ascospore release by Venturia inaequalis. In three separate experiments at each temperature, samples were exposed to simulated rain and light for $6 \mathrm{~h}$ at $\mathbf{A}, 1^{\circ} \mathrm{C}$; or for $3 \mathrm{~h}$ at $\mathbf{B}, 2 ; \mathbf{C}, 4 ; \mathbf{D}, 6$; or $\mathbf{E}, 8^{\circ} \mathrm{C}$, followed by $3 \mathrm{~h}$ at $20^{\circ} \mathrm{C}$. 

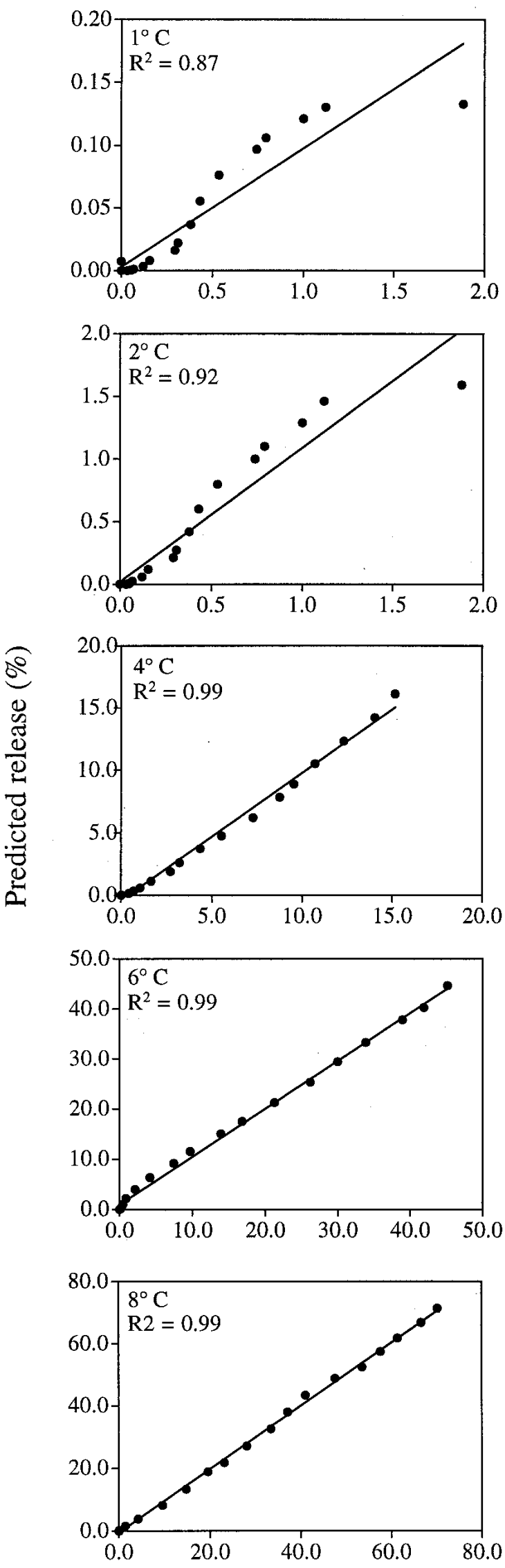

\section{Observed release (\%)}

Fig. 4. Correlation of observed cumulative release of ascospores of Venturia inaequalis at 1 to $8^{\circ} \mathrm{C}$ and cumulative release as predicted by equation 1 . At each temperature, linear regression was used to describe the correlation between expected and observed values. sence of detectable infection even though the minimum environmental criteria for ascosporic infection are met or exceeded.

Although substantial progress has been made in quantifying the effects of temperature on the infection process $(1,20,22,26,38)$, the direct impact of temperature on the availability of ascospores is currently not considered in spray advisory programs. Given the substantial delay in spore release, the reduced rate of release, and the resultant reduction of airborne ascospore dose below $2^{\circ} \mathrm{C}$, there may be a potential to withhold fungicide sprays when rain occurs at very low temperatures.

As far as we are aware, this report provides the first experimental evidence for minimum infection times at temperatures below $3.9^{\circ} \mathrm{C}$ for conidia and $4.9^{\circ} \mathrm{C}$ for ascospores. Roosje $(30,31)$, Moore (28), and Schwabe (32) reported that the time needed for ascospore infection was less than for conidia, as did equations reported by MacHardy and Gadoury (22), which are based on a composite of the above data. Our results indicate that little substantial difference exists in the minimum infection times for either spore type at $8^{\circ} \mathrm{C}$ or less.

There was a clear curvilinear relationship between temperature and time needed for infection between 2 and $8^{\circ} \mathrm{C}$. At temperatures of 6 or $8^{\circ} \mathrm{C}$, infection by ascospores occurred after approximately two-thirds the time reported by Mills and Laplante (27). At and below $4^{\circ} \mathrm{C}$, we also found that infections occurred much earlier (Table 2) than the "more than 2 days" reported by Mills and Laplante (27). Our results are in accordance with the minimum time needed for infection at $6^{\circ} \mathrm{C}$ in the studies of Keitt and Jones (17) and at 7.2 and $7.8^{\circ} \mathrm{C}$ of Preece (29). We observed infections in slightly shorter times than reported by Sys and Soenen (37) and Schwabe (32). Turner et al. (38) reported that $10 \%$ of all ascospores and conidia had formed appressoria after 16.6 and $12.5 \mathrm{~h}$, respectively, at $5^{\circ} \mathrm{C}$ on apple leaves. Thus, at least $10 \%$ of ascospores and conidia have formed appressoria $\approx 5$ to $11 \mathrm{~h}$ before our equations would indicate that infection had occurred at $5^{\circ} \mathrm{C}$. The preponderance of experimental evidence indicates that both ascosporic and conidial infection occurs in far less time than suggested by Mills and LaPlante (27) and that the disparity is greatest at low temperatures.

Mills' table for infection was developed after numerous years of trials and observations in the field. At least some of the difference between our results and those of Mills and Laplante (27) for infection by ascospores might be explained by the delay of ascospore release and, thus, the time of inoculation at temperatures near $2^{\circ} \mathrm{C}$ in the field. In only one previous study (32) was delayed ascospore release at low temperatures considered in the interpretation of experimental results. However, given that 40 to $50 \%$ of the available ascospores were discharged within $3 \mathrm{~h}$ at $6^{\circ} \mathrm{C}$ (Fig. 3), it is unlikely that delayed release would explain the 9 to $12 \mathrm{~h}$

TABLE 1. Expected and observed release of ascospores by three populations of Venturia inaequalis at 1 and $2^{\circ} \mathrm{C}$

\begin{tabular}{|c|c|c|c|c|c|}
\hline \multirow{2}{*}{$\begin{array}{l}\text { Temp. } \\
\left({ }^{\circ} \mathrm{C}\right) \\
\end{array}$} & \multirow{2}{*}{$\begin{array}{l}\text { Time } \\
(\mathrm{h})^{\mathrm{a}}\end{array}$} & \multirow{2}{*}{$\begin{array}{c}\text { Expected } \\
(\%)^{\mathrm{b}}\end{array}$} & \multicolumn{3}{|c|}{ Observed $(\%)^{\mathrm{c}}$} \\
\hline & & & New York & Sweden & Germany \\
\hline \multirow[t]{4}{*}{1} & 1 & 0.00 & 0.00 & 0.00 & 0.00 \\
\hline & 3 & 0.13 & 0.16 & 0.09 & 0.23 \\
\hline & 6 & 0.64 & 0.77 & 1.01 & 0.93 \\
\hline & 12 & 1.58 & 2.91 & 2.08 & 1.44 \\
\hline \multirow[t]{4}{*}{2} & 1 & 0.01 & 0.06 & 0.02 & 0.04 \\
\hline & 3 & 1.59 & 2.26 & 0.94 & 3.03 \\
\hline & 6 & 4.83 & 6.55 & 4.66 & 6.40 \\
\hline & 12 & 10.91 & 13.89 & 11.01 & 12.18 \\
\hline
\end{tabular}

a Time from initial wetting.

${ }^{\mathrm{b}}$ Expected values for both 1 and $2^{\circ} \mathrm{C}$ at 1 and $3 \mathrm{~h}$ were generated by equation 1 ; values at 6 and $12 \mathrm{~h}$ were generated by equations 2 and 3 for 1 and $2{ }^{\circ} \mathrm{C}$, respectively.

c Ascospores were harvested in a previously described apparatus (11) from overwintered leaf samples collected at Geneva, NY; Alnarp, Sweden; and Friedrichschafen, Germany. 
difference between the minimum infection times that we found at $6^{\circ} \mathrm{C}$ or the 20 to $21 \mathrm{~h}$ difference at $4^{\circ} \mathrm{C}$ compared to those suggested by Mills (26).

Inoculum dose of $V$. inaequalis currently is not considered in calculating the minimum times required for infection at various temperatures but was discussed by MacHardy (20). Wilcox (39) showed inoculum dose to be an important factor in minimum infection times for brown rot of stone fruit, caused by Monilinia fructicola. Doses used in laboratory inoculations usually are much higher than those that occur in an orchard. Use of highly concentrated conidial suspensions and placement of heavily infected leaves directly above plants results in comparatively large numbers of spores per leaf. In contrast, ascosporic infections in orchards usually involve interception of a single spore by a single leaf. For the present, we have demonstrated that at temperatures below those investigated by Mills (26), infection can occur in substantially less time than he suggested. Although it is probable that minimum infection times would be increased by lower inoculum doses, further work is needed before the magnitude of that effect is known.

Primary infections during early spring also can originate from conidia developing in twig lesions and bud scales $(2,12,18,19,24$, 36). Some commercially grown apple cultivars in Norway readily develop twig lesions, especially where scab control has been poor (36). Conidia from such sources can be quickly dispersed in water films or splash droplets to emerging apple tissue. Furthermore, the inoculum dose in such films and droplets may more closely approximate that used in laboratory studies. In several countries, growers use Mills' (26) criteria as an advisory for curative spraying against apple scab, independent of the history of disease control (20). At low temperatures, infections should be expected to occur from such conidial sources after much shorter periods of wetness than are given in Mills' table.

We defined our minimum infection times as the minimum time required for successful infection of any quantity of tissue on potted trees. We did not attempt to construct a frequency distribution of infection versus time. The construction of such a distribution from our ascosporic infection data would have been problematic, because inoculum presumably was discharged onto the plants at a high rate during the first few minutes at all temperatures and declined as the leaves were cooled at low temperatures (10). The response we measured indicated more precisely the minimum time required after arrival of inoculum for successful infection and establishment in leaf tissue. Mills' original paper (26) described the approximate number of hours of wetting necessary for three levels (light, moderate, and severe) leaf infection by ascospores in an orchard containing "an abundance of inoculum." Mills (26) did not define the quantitative levels of disease expected as the duration of wetting increased at a given temperature. Consequently, most integrated pest management programs currently recommend, and most growers use, the minimum criteria given by Mills or subsequent revisions of Mills' criteria $(14,22)$ in making decisions on use of fungicides to control apple scab.

In our opinion, minimum infection times are more likely to be used in disease management decisions. However, for simulation studies, and perhaps for future use in management decisions, construction of a distribution of infection versus time would be desirable. In the case of ascospores, there are distributions of release and establishment (germination, appressorium formation, and successful infection) to be considered. The variation in rate of germination and appressorium formation of ascospores and conidia at various temperatures was described by Turner et al. (38). A later study by Smereka et al. (34) suggested that the rates observed by Turner et al. (38) could have slightly underestimated total infection, because infection by direct penetration without appressorium formation was not detected by Turner et al. (38). However, assuming that this potential bias was applied uniformly at all temperatures, the distributions generated by Turner et al. (38) would still be useful. In combination with our model of the effects of temperature on the rate of ascospore release, it should now be possible to more accurately simulate the distribution of infection and lesion formation versus time at various temperatures. Until data are available on the release and dispersal of conidia versus time, it is necessary to assume that conidial inoculation is coincident with the onset of rain.

Impact on warning systems and recommendations for use of minimum criteria for infection. It is important to distinguish between the effects of temperature on the discharge of ascospores and the effects of temperature on the infection process. Low temperatures will delay the arrival and reduce the dose of ascosporic, but not conidial, inoculum. The extension of minimum infection times due to the delay of ascospore release is most likely to be significant at temperatures of $2^{\circ} \mathrm{C}$ or less. At temperatures below $2^{\circ} \mathrm{C}$, ascospore release is virtually nil for several hours. Even after release begins, the rate of ascospore release remains extremely low. Of course, at extremely high inoculum levels, the absolute number of ascospores released could be significant, even though it represents a small proportion of the total inoculum available. However, many commercial orchards harbor little overwintering ascosporic inoculum (8). Therefore, detectable disease may not follow infection periods at temperatures near freezing, due to delayed ascospore release, reduced rate of release, and consequent low airborne ascospore dose. No such disparity is anticipated for conidial inoculum: no previous studies have demonstrated reduced production, release, or dispersal during cold wetting periods, neither is a disparity anticipated for ascosporic infection at high inoculum levels.

It may be possible, as a preliminary step, to increase the minimum infection times for ascospores by adding the time required for initial ascospore release $(\approx 2.5,2.3,1.1,0.9$, and $0.7 \mathrm{~h}$ at 1,2 , 4,6 , and $8^{\circ} \mathrm{C}$, respectively) to the times generated by our equation 4 (Fig. 1). However, further clarification of the impact of airborne ascospore dose on apparent minimum infection times also would

TABLE 2. Minimum number of hours of leaf wetness required for infection of apple leaves by ascospores and conidia of Venturia inaequalis

\begin{tabular}{|c|c|c|}
\hline \multirow{2}{*}{$\begin{array}{l}\text { Temp. } \\
\left({ }^{\circ} \mathrm{C}\right)\end{array}$} & \multicolumn{2}{|c|}{ Minimum no. of hours of leaf wetness required ${ }^{a}$} \\
\hline & Ascospores & Conidia \\
\hline 1 & 40.5 & 37.4 \\
\hline 2 & 34.7 & 33.6 \\
\hline 3 & 29.6 & 30.0 \\
\hline 4 & 27.8 & 26.6 \\
\hline 5 & 21.2 & 23.4 \\
\hline 6 & 18.0 & 20.5 \\
\hline 7 & 15.4 & 17.8 \\
\hline 8 & 13.4 & 15.2 \\
\hline 9 & 12.2 & 12.6 \\
\hline 10 & 11.0 & 10.0 \\
\hline 11 & 9.0 & 9.5 \\
\hline 12 & 8.3 & 9.3 \\
\hline 13 & 8.0 & 9.2 \\
\hline 14 & 7.0 & 9.2 \\
\hline 15 & 7.0 & 9.2 \\
\hline 16 & 6.1 & 9.0 \\
\hline 17 & 6.0 & 8.8 \\
\hline 18 & 6.0 & 8.5 \\
\hline 19 & 6.0 & 8.2 \\
\hline 20 & 6.0 & 7.9 \\
\hline 21 & 6.0 & 7.8 \\
\hline 22 & 6.0 & 7.8 \\
\hline 23 & 6.0 & 8.3 \\
\hline 24 & 6.1 & 9.3 \\
\hline 25 & 8.0 & 11.1 \\
\hline 26 & 11.3 & 14.0 \\
\hline
\end{tabular}

a Times at temperatures from 1 to $8^{\circ} \mathrm{C}$ are from equations 1 and 2 . Time at $9^{\circ} \mathrm{C}$ is an interpolation from equations 1 and 2 at $8.0^{\circ} \mathrm{C}$ and data of $\mathrm{MacHardy}$ and Gadoury (22) for $10.0^{\circ} \mathrm{C}$. Times at temperatures from 10 to $26^{\circ} \mathrm{C}$ are from MacHardy and Gadoury (22). 
allow us to refine the minimum times by accounting for delayed ascospore release and reduced airborne ascospore dose. Until such studies are completed, the new criteria can still be used independently of the influence of temperature on ascospore release. Indeed, because we found minimum infection times that were substantially shorter than those reported by Mills at low temperatures (26), or in subsequent revisions of his criteria $(14,22)$, adoption and application of our criteria should lower the overall risk of undetected infection in management of apple scab.

MacHardy and Gadoury (22) recommended that the initiation of an ascosporic infection period should be delayed until $0700 \mathrm{~h}$. when rain begins at night (1800 to $0700 \mathrm{~h})$. They also generated new minimum criteria for infection by ascospores and conidia, based on manipulations of Mills' original table for ascosporic infection and on other published data on minimum infection requirements for conidia (22). However, the revised criteria that they recommended still lacked supporting data for temperatures below $6^{\circ} \mathrm{C}$. We can now synthesize a table of minimum infection times for ascospores and conidia for temperatures from 1 to $26^{\circ} \mathrm{C}$ from a compilation of published data (Table 2). Minimum infection times for 1 to $8^{\circ} \mathrm{C}$ were generated from our equations 4 and 5 (Figs. 1 and 2), although the times for $1^{\circ} \mathrm{C}$ were extrapolated below the range of our data. Minimum infection times for $9^{\circ} \mathrm{C}$ are an interpolation between times for $8^{\circ} \mathrm{C}$ generated by our equations 4 and 5 and times for $10^{\circ} \mathrm{C}$ reported by MacHardy and Gadoury (22). Minimum infection times for 10 to $26^{\circ} \mathrm{C}$ (Table 2) are those reported by MacHardy and Gadoury (22).

As a further modification of Mills' (26) original infection periods, we recommend a conservative application of our criteria. There are few substantial $(>10 \%)$ differences in minimum infection times required for ascosporic versus conidial infection below $11^{\circ} \mathrm{C}$, but minimum times estimated for ascosporic infection are $\approx 30 \%$ shorter than those for conidia from 16 to $24^{\circ} \mathrm{C}$. Therefore, although both spore forms may be present simultaneously during the early growing season, we recommend the use of the minimum criteria described for ascospores prior to the exhaustion of the ascospore supply. Once the supply of ascospores is exhausted, the criteria for conidial infection should be applied. As late-spring and summer temperatures increase, the mean temperature during most infection periods exceeds $11^{\circ} \mathrm{C}$ (i.e., fall in the range in which conidia are estimated to require significantly more time than ascospores to infect).

We would like to present our further refinements of minimum infection criteria in their proper perspective. They are based on environmental conditions only and should not be considered apart from the influence of host growth and inoculum dose on the eventual quantity of disease resulting from an infection event. A number of previous studies have illustrated that environmental conditions conducive to "severe" infection sensu Mills (27) may not result in detectable disease prior to the pink stage of fruit bud development when inoculum dose is low $(9,20,23,35)$. Conversely, more recent preliminary studies $(5,6)$ have indicated that severe disease can follow minimal environmental conditions for infection when host target size, tissue susceptibility, and airborne inoculum dose collectively favor the development of severe disease between the tight-cluster and bloom stages of fruit bud development. Increasing the duration of a wetting interval to longer than the minimal times at any given temperature generally has produced anywhere from a two- to five-fold increase in disease severity (20). In contrast, airborne ascospore dose and target size and susceptibility can vary in excess of three orders of magnitude $(5,8,20,23)$ and can be expected to produce equivalent variation in disease severity. The accurate identification of the minimal time required for infection at a given temperature is a necessary first step in a logical sequence of calculations to predict the severity of disease after an infection event. Once minimal conditions are satisfied, the consequent severity of disease is likely to be more substantially impacted by inoculum dose and target size and susceptibility than by additional hours of wetting. Further research in this area may allow a more quantitative estimate of risk based on factors other than weather alone. However, an inaccurate model of minimal infection times will only confound the interpretation data collected in such studies and may result in inaccurate forecasts of infection when precise knowledge of inoculum dose and target size and susceptibility are lacking (as is currently the case in most commercial orchards). For these reasons, we have recommended the immediate adoption of the revised criteria. We recognize that this occasionally will result in forecasts that are not followed by significant infection. This is also a potential source of error in all earlier systems that similarly use weather alone to forecast infection. However, the risk of undetected infection (in particular at low temperatures) has been reduced greatly by the current revision.

\section{ACKNOWLEDGMENTS}

We thank J. Barnard for his help in developing the model of ascospore release and our many colleagues who collected leaf samples for this study.

\section{LITERATURE CITED}

1. Becker, C. M., and Burr, T. J. 1994. Discontinuous wetting and survival of conidia of Venturia inaequalis on apple leaves. Phytopathology 84: 372-378.

2. Becker, C. M., Burr, T. J., and Smith, C. A. 1992. Overwintering of conidia of Venturia inaequalis in apple buds in New York orchards. Plant Dis. 76:121-126.

3. Brook, P. J. 1966. The ascospore production season of Venturia inaequalis (Cke.) Wint., the apple black spot fungus. N.Z. J. Agric. Res. 9: 1064-1069.

4. Brook, P. J. 1969. Effects of light, temperature, and moisture on release of ascospores by Venturia inaequalis (Cke.) Wint. N.Z. J. Agric. Res. 12:214-227.

5. Falk, S., Gadoury, D. M., and Seem, R. C. 1995. Analysis of risk of primary apple scab infection. (Abstr.) Phytopathology 85:1556.

6. Falk, S. P., Gadoury, D. M., and Seem, R. C. 1996. Impact of ontogenic resistance and fenarimol on seasonal development of scab on apple fo liage. (Abstr.) Phytopathology 86 (Suppl.):S85.

7. Frey, C. N., and Keitt, G. W. 1925. Studies of spore dissemination of Venturia inaequalis (Cke.) Wint. in relation to seasonal development of apple scab. J. Agric. Res. 15:529-540.

8. Gadoury, D. M., and MacHardy, W. E. 1986. Forecasting ascospore dose of Venturia inaequalis in commercial apple orchards. Phytopathology 76: 112-118.

9. Gadoury, D. M., MacHardy, W. E., and Rosenberger, D. A. 1989. Integration of pesticide application schedules for disease and insect control in apple orchards of the northeastern United States. Plant Dis. 73: 98-105.

10. Gadoury, D. M., Seem, R. C., and Stensvand, A. 1994. Ascospore discharge in Venturia inaequalis. Nor. J. Agric. Sci. Suppl. 17:205-219.

11. Gadoury, D. M., Stensvand, A., and Seem, R. C. 1996. A wind tunnel for controlled-environment studies of ascospore release by Venturia inaequalis. Phytopathology 86:596-601.

12. Hill, S. A. 1975. The importance of wood scab caused by Venturia inaequalis (Cke.) Wint. as a source of infection for apple leaves in the spring. Phytopathol. Z. 82:216-223.

13. Hirst, J. M., and Stedman, O. J. 1962. The epidemiology of apple scab (Venturia inaequalis (Cke.) Wint.) II. Observations on the liberation of ascospores. Ann. Appl. Biol. 50:525-550.

14. Jones, A. L., and Aldwinckle, H. S. 1990. Compendium of Apple and Pear Diseases. The American Phytopathological Society, St. Paul, MN.

15. Jones, A. L., Lillevik, S. L., Fisher, P. D., and Stebbins, T. C. 1980. A microcomputer-based instrument to predict primary apple scab infection periods. Plant Dis. 64:69-72.

16. Keitt, G. W. 1927. Studies of the apple scab and cherry leaf spot infection under controlled conditions. (Abstr.) Phytopathology 17:45.

17. Keitt, G. W., and Jones, L. K. 1926. Studies of the epidemiology and control of apple scab. Wis. Agric. Exp. Stn. Res. Bull. 73.

18. Kennel, W. 1987. Kelchblätter als erste Objekt für Apfelschorf. Erwerbsobstbau 29(2):36-38.

19. Kennel, W. 1990. Die Überwinterung des Apfelschorfs. Obstbau 8:346-347.

20. MacHardy, W. E. 1996. Apple Scab. The American Phytopathological Society, St. Paul, MN.

21. MacHardy, W. E., and Gadoury, D. M. 1986. Patterns of ascospore dis- 
charge by Venturia inaequalis. Phytopathology 76:985-990.

22. MacHardy, W. E., and Gadoury, D. M. 1989. A revision of Mills's criteria for predicting apple scab infection periods. Phytopathology 79:304310. Erratum 81:809.

23. MacHardy, W. E., Gadoury, D. M., and Rosenberger, D. A. 1993. Delaying the onset of fungicide programs for control of apple scab in orchards with low potential ascospore dose of Venturia inaequalis. Plant Dis. 77: 372-375.

24. Marsh, W., and Walker, M. 1932. The scab fungus (Venturia inaequalis) on apple shoots. J. Pomol. Hortic. Sci. 10:71-90.

25. McCullagh, P., and Nelder, J. A. 1983. Generalised Linear Models. Chap-man and Hall, London.

26. Mills, W. D. 1944. Efficient use of sulfur dusts and sprays during rain to control apple scab. Cornell Ext. Bull. 630.

27. Mills, W. D., and Laplante, A. A. 1951. Diseases and insects in the orchard. Cornell Ext. Bull. 711:21-27.

28. Moore, M. H. 1964. Glasshouse experiments in apple scab. I. Foliage infection in relation to wet and dry periods. Ann. Appl. Biol. 53:423-435.

29. Preece, T. F. 1964. Continuous testing for scab infection weather using apple rootstocks. Plant Pathol. 13:6-9.

30. Roosje, G. S. 1955. Laboratoriumonderzoek over de biologie en de bestrijding van de Venturia inaequalis (Cke.) Wint. Meded. Direct. van de Tuinbouw 18:139-151.

31. Roosje, G. S. 1963. Research on apple and pear scab in the Netherlands from 1938 until 1961. Neth. J. Plant Pathol. 69:132-137.
32. Schwabe, W. F. S. 1980. Wetting and temperature requirements for apple leaf infection by Venturia inaequalis in South Africa. Phytophylactica 12: 69-80.

33. Seem, R. C., Gilpatrick, J. D., and Szkolnik, M. 1979. Quantitative effects of microclimate on spore development and dispersal systems of apple scab. Pages 135-137 in: Proc. Symp. 9th Int. Congr. Plant Prot. Burgess Publishing Co., Minneapolis.

34. Smereka, K. J., MacHardy, W. E., and Kausch, A. P. 1987. Cellular differentiation in Venturia inaequalis ascospores during germination and penetration of apple leaves. Can. J. Bot. 65:2549-2561.

35. Stensvand, A., and Amundsen, T. 1996. Investigations on the potential ascospore dose of Venturia inaequalis in Norwegian apple orchards. Proc. 4th Workshop Integr. Control Pome Fruit Dis. In press.

36. Stensvand, A., Amundsen, T., and Semb, L. 1996. Observations on wood scab caused by Venturia inaequalis and $V$. pirina in apple and pear orchards in Norway. Nor. J. Agric. Sci. 10:533-540.

37. Sys, S., and Soenen, A. 1970. Investigation on the infection criteria of scab (Venturia inaequalis (Cooke) Winter) on apples with respect to the table of Mills and Laplante. Agricultura 18:3-8.

38. Turner, M. L., MacHardy, W. E., and Gadoury, D. M. 1986. Germination and appressorium formation by Venturia inaequalis during infection of apple seedling leaves. Plant Dis. 70:658-661.

39. Wilcox, W. F. 1989. Influence of environment and inoculum density on the incidence of brown rot blossom blight of sour cherry. Phytopathology 79:530-534. 